$\xi=$

\title{
The ethnomedicine of the Batak Karo people of Merdeka sub-district, North Sumatra, Indonesia
}

\author{
Endang Christine Purba ${ }^{1 *}$, Nisyawati $^{1}$, Marina Silalahi ${ }^{2}$ \\ ${ }^{1}$ Program Studi Biologi, Program Pascasarjana, Fakultas Matematika dan Ilmu Pengetahuan Alam, Universitas Indonesia \\ ${ }^{2}$ Program Studi Pendidikan Biologi FKIP Universitas Kristen Indonesia \\ *Corresponding author E-mail: endang.christine@yahoo.com
}

\begin{abstract}
Background: Ethnomedicine can serve as a platform for studying specific relationships between indigenous cultures and using medicinal plants, thus to identify new chemical compounds used as drugs.

Objective: To document the medicinal plants and traditional medicines used by Batak Karo people and to provide information on the pharmacological properties of the most commonly used plants in the preparation to treat of various ailments especially preventive healthcare.

Methods: The ethnobotanical study was conducted in Merdeka sub-district, Karo regency, North Sumatra, Indonesia. An intensive field survey was conducted to collect information on medicinal plants used by the people. Data was collected applying semi-structured interviews (individual and group discussions) and questionnaires.

Results: A total of 124 plants species have been documented to treat various diseases. Zingiberaceae is the highest number of species being used as traditional medicines especially concoction of preventive healthcare. The study revealed that fever is treated using the highest number of different medicinal species (23 species).

Conclusion: Batak Karo people in Merdeka sub-district have a rich local knowledge about medicinal plants. It is a need to extend the documentation of medicinal plants in the area and evaluation its biological activity as a basis for developing future medicines.
\end{abstract}

Keywords: Ethnomedicine; Batak Karo; Indonesia.

\section{Introduction}

Based on old records Heyne there are about 5000 species of useful plants in Indonesia which constitutes $3 \%$ of the medicinal plants (Kartawinata 2004). Approximately the total number today is greater than those earlier results. To overcome this, an effective way to find new medicinal plants is to follow the indigenous knowledge (Mendelsohn \& Balick 1995, Balick \& Cox 1997, Sam et al. 2008, Guimbo 2011). Ethnobotanical can serve as a platform for studying specific relationships between indigenous cultures and using medicinal plants, thus to identify new chemical compounds used as drugs (Balick \& Cox 1997, Heinrich 2000, Fabricant \& Farnsworth 2001). Research based on local people perspective, will be good strategy to make conservation investment, and to identify what kind of sustainable incentives can be delivered. The province of North Sumatra is home to Batak ethnic. It comprises six sub-ethnic: Karo, Toba, Simalungun, Mandailing, Pakpak and Angkola (Singarimbun 1975). The Karo is a group of local people who inhabitat Karoland (Taneh Karo) in North Sumatra, Indonesia. The Karoland is an area mainly consisting of mountains (Sinabung and Sibayak) and highlands (Anderson 1971, Singarimbun 2007). These good circumstances has made Batak Karo people are known to have utilized plants which related to its cultural for many years and still practice and maintain it such as traditional medicine (Singarimbun 1975, Penny \& Singarimbun 2007, Silalahi et al. 2015). They use many medicinal plant species which known to have efficacy to maintain the health or to cure disease. Ethnomedicinal plants used by Batak Karo in different villages of Karo regency have also been reported recently such as in Tongkoh (Sembiring et al. 2013) and Kaban Tua (Silalahi 2014). Semangat Gunung, Jaranguda and Merdeka are closed to Bukit Barisan highland. They are arranged in a densely populated core, with forest and fields on the pheriphery. The dense forest near the villages has made them rich in floral resources and prosperous in medicinal plants species wealth. Based on our knowledge, there are no reports regarding to ethnomedicinal aspects of Karo of Merdeka sub-district. For that aim, an ethnobotanical research has been conducted on Batak Karo society in Merdeka sub-district. To analyze the role of medicinal plants of Karo, this research deals with the variety of medicinal plants and its uses.

\section{Materials and methods}

\subsection{Study area}

The ethnobotanical study was conducted during April - June 2014 in Semangat Gunung, Jaranguda, and Merdeka villages, Karo regency, North Sumatra, Indonesia (elevation 1,162-1,453 m above sea level) (Figure 1). The average annual temperate was 16 to $17{ }^{\circ} \mathrm{C}$. Merdeka village is the capital of Merdeka sub-district. Semangat Gunung is about $8.39 \mathrm{~km}^{2}$ and $16 \mathrm{~km}$ from Merdeka. Jaranguda is $5.46 \mathrm{~km}^{2}$ and $2 \mathrm{~km}$ from Merdeka. More than $95 \%$ of the Batak Karo people in Merdeka sub-district are farmers. They plant tomato, cabbage, potato, chili and carrot. 


\subsection{Data collection}

Ethnobotanical data were obtained through semi-structured interviews (individual and group discussions) and questionnaires. A snowball method was conducted to select the respondents beginning with the village leader and traditional doctors (Bernard 2002). There are 3 village leader and 3 traditional doctors in the research area. Surveys and interviews were carried out in 87 respondents. The standard interviews contained specific questions on gender, age and main users of plant products. Several questions concerning about medical plants were addressed to determine the local names of plants, parts of plants they used and for what purpose.

This research was also used to collect specimens for identification of the used plants which organized by key informants. The identification of the specimens was deposited at the Herbarium of Universitas Indonesia, Depok, Indonesia. Scientific names of the plants species were verified using The Plant List online source.

\section{Result}

A total of 124 medicinal plant species are used by Batak Karo ethnic society in Semangat Gunung belonging to 107 genera and
52 families (Table 1). Among all the families, Zingiberaceae is the highest number of plant species, 15 species (Figure 2). The 124 medicinal plants species are used to treat of 39 different diseases. The highest numbers of medicinal plants ( 23 species) are used for the treatment of fever. Fever included a symptom caused by some diseases which mainly focusing on lowering body temperatures. Moreover, $71 \%$ of the species are collected from the wild. These are all plants naturally occurring in different vegetation types e.g.: forest, along roads, shrubbery and agricultural fields. Twenty three of the species are cultivated in home gardens, fields and along the village road. Six percent of the species are both taken from the wild and also grown in the agricultural fields or home gardens. Herbs (74 species) are found to be the most used plants followed by wood (36 species), shrubs (11 species), lianas ( 2 species) and lichen (1 species). Leaves are most commonly used by Batak Karo, comprising $51 \%$ of all the results on use of plant parts. This is followed by root $(10 \%)$, rhizome $(8 \%)$, flower $(7 \%)$, stem $(7 \%)$, fruit $(6 \%)$, whole plant $(6 \%)$, bark $(2 \%)$, seed $(2 \%)$, tuber $(1 \%)$ and latex (1\%) (Table 2). Traditional concoctions are minak, tawar, kuning, and oukup.

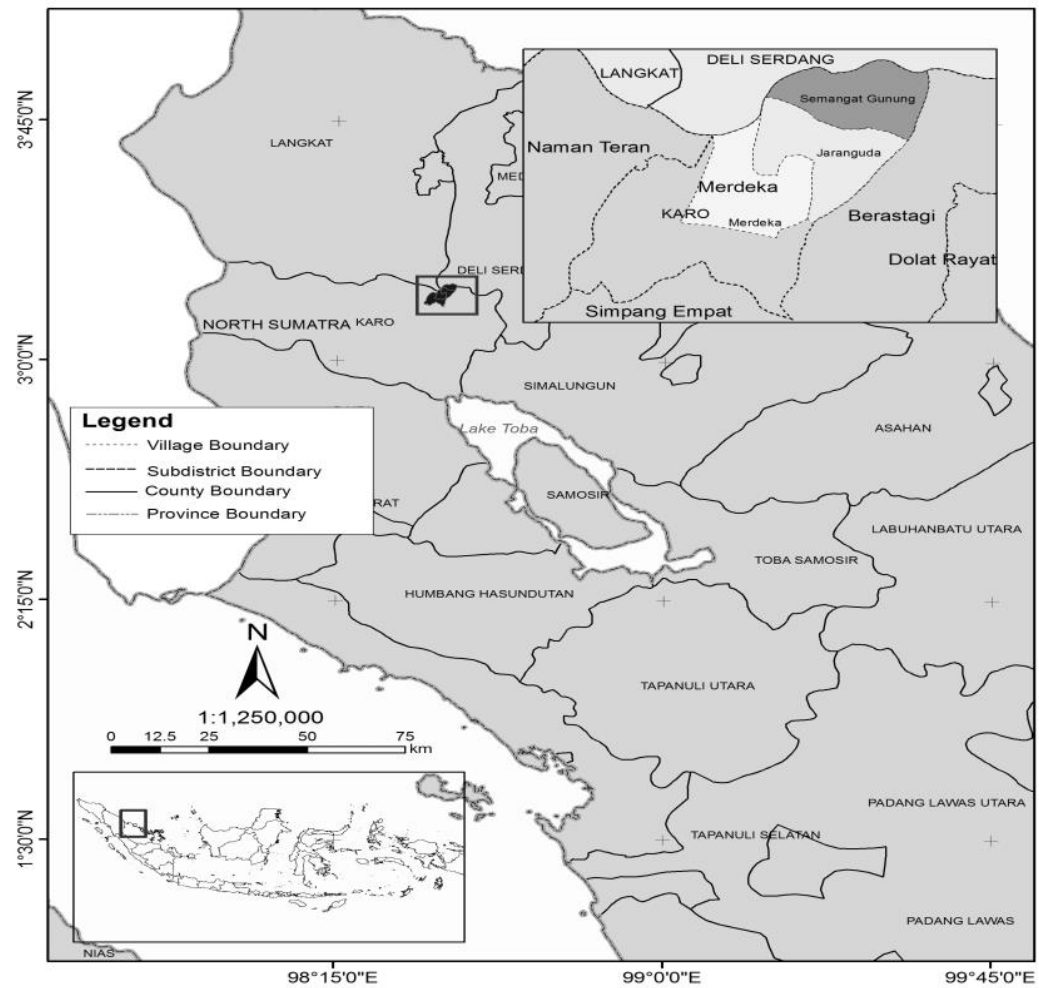

Fig. 1: Map of Merdeka Sub-District, Karo Regency, North Sumatra, Indonesia.

Table 1: Medicinal Plants Species Used By Batak Karo People in Merdeka Sub-District. Plabt Sources: W (Wild), C (Cultivated). Part Utilized: B (Bark), L (Leaf), La (Latex), Fl (Flower), Fr (Fruit), Rh (Rhizome), Ro (Root), Se (Seed), St (Stem), T (Tuber), and Wp (Whole Plant).

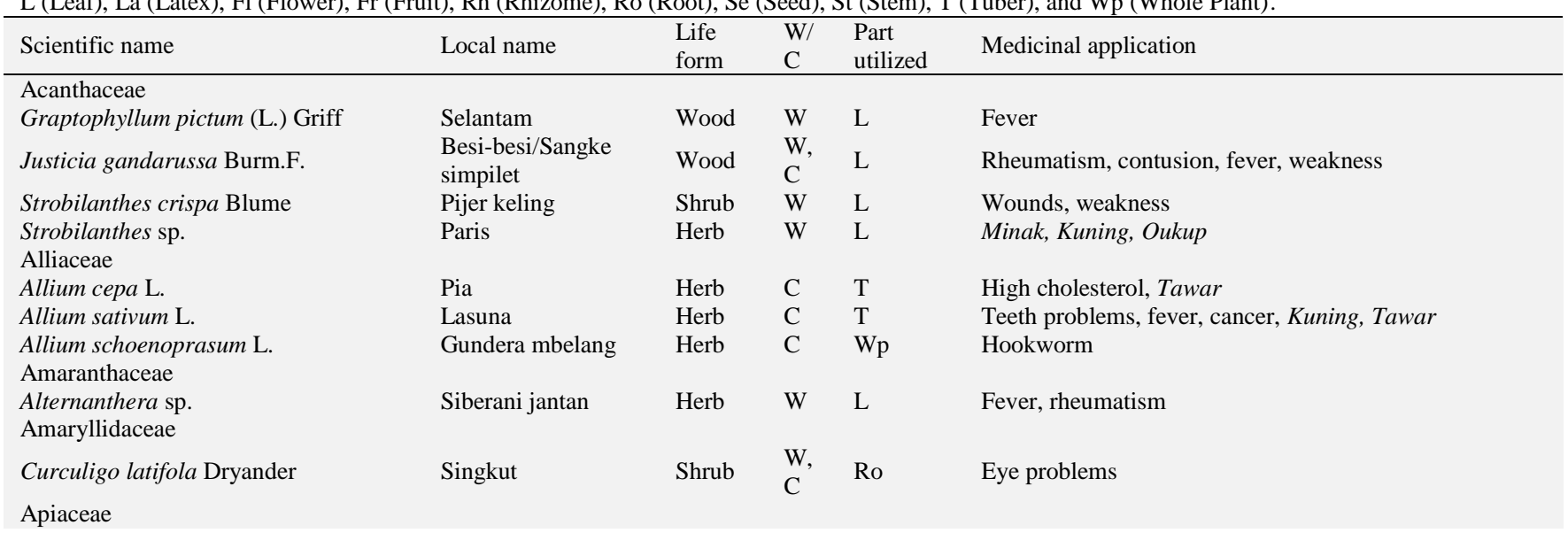




\begin{tabular}{|c|c|c|c|c|c|}
\hline Centella asiatica (L.)Urb. & Pegaga & Herb & $\mathrm{W}$ & $\mathrm{L}$ & $\begin{array}{l}\text { Abscesses, wounds, bone fractures, blood circulation } \\
\text { problem, abscesses }\end{array}$ \\
\hline $\begin{array}{l}\text { Coriandrum sativum } \mathrm{L} \text {. } \\
\text { Araceae }\end{array}$ & Ketumbar & Herb & $\mathrm{W}$ & $\mathrm{Fr}$ & Diarrhea, Oukup \\
\hline Acorus calamus $\mathrm{L}$. & Jerango & Herb & $\begin{array}{l}\mathrm{W} \\
\mathrm{C}\end{array}$ & L, Ro & Fever, coughs, Oukup \\
\hline $\begin{array}{l}\text { Homalomena sp. } \\
\text { Arecaceae }\end{array}$ & Langge megara & Herb & $\mathrm{W}$ & $\mathrm{L}$ & Fever \\
\hline Areca catechu $\mathrm{L}$. & Mayang & Wood & $\mathrm{W}$ & $\begin{array}{l}\text { Fr, St, } \\
\text { Ro }\end{array}$ & Burns, heartburn, weakness, Tawar, Minak \\
\hline Arenga pinnata (Wurmb) Merr & Pola & Wood & $\mathrm{W}$ & Ro, St & Fever, Tawar \\
\hline Calamus diepenhorstii Miq. & Ketang & Liana & W & L, St, Ro & Stomache ache,Tawar \\
\hline Cocos nucifera $\mathrm{L}$. & Tualah & Wood & $\begin{array}{l}\mathrm{W} \\
\mathrm{C}\end{array}$ & Fr,St,Ro & Smallpox, fever, Tawar, Minak \\
\hline $\begin{array}{l}\text { Nipa fruticans (Wurmb).Thunb } \\
\text { Asclepiadaceae }\end{array}$ & Nipah & Wood & $\mathrm{W}$ & L,St, Ro & Gastritis, Tawar \\
\hline $\begin{array}{l}\text { Hoya } \text { sp. } \\
\text { Aspleniaceae }\end{array}$ & Tawar ipoh & Herb & W & $\mathrm{L}$ & Weakness, cancer, Tawar, Minak \\
\hline $\begin{array}{l}\text { Asplenium sp. } \\
\text { Asteraceae }\end{array}$ & Peldang & Herb & $\mathrm{W}$ & $\mathrm{L}$ & Bone fractures \\
\hline Bidens chinensis Willd & Kalesi & Herb & $\mathrm{W}$ & $\mathrm{L}$ & $\begin{array}{l}\text { Burns, blood circulation problem, appetite enhancer, } \\
\text { liver, }\end{array}$ \\
\hline Artemisia vulgaris Linn & Binara embang & Herb & $\mathrm{W}$ & $\mathrm{L}$ & Hemorrhoids, dysmenorrheal \\
\hline Centipeda minima $\mathrm{P}$. & Pecah pinggan & Herb & $\mathrm{W}$ & $\mathrm{L}$ & Weakness \\
\hline $\begin{array}{l}\text { Chromolaena odorata (L.) R.M. King } \\
\text { \& H. Rob. }\end{array}$ & Sipesel & Herb & W & $\mathrm{L}$ & Bone fractures, Tawar \\
\hline $\begin{array}{l}\text { Crassocephalum crepidioides (Benth.) } \\
\text { S. Moore }\end{array}$ & Sabi-sabi & Herb & $\mathrm{W}$ & $\mathrm{L}$ & Wounds \\
\hline $\begin{array}{l}\text { Dicrocephala integrifolia (L. f.) } \\
\text { Kuntze }\end{array}$ & Sirahrah & Herb & W & $\mathrm{L}$ & Fever \\
\hline Erigeron sumatrensis Retz. & Ciak-ciak & Herb & $\mathrm{W}$ & $\mathrm{L}$ & Stomach ache, wounds \\
\hline Eupatorium odaratum L. & Lenga-lenga & Shrub & $\mathrm{W}$ & $\mathrm{L}$ & Bladder stones \\
\hline Lagenophora lanata A. Cunn & Sibelin urat & Herb & $\mathrm{W}$ & $\mathrm{Wp}$ & Weakness \\
\hline Spilanthes iabadicensis A.H. Moore & Sibancir & Herb & $\mathrm{W}$ & $\mathrm{L}$ & Colds, Diabetes \\
\hline $\begin{array}{l}\text { Tithonia diversifolia (Hemsl) A. Gray } \\
\text { Balsaminaceae }\end{array}$ & Pagit-pagit & Shrub & $\mathrm{W}$ & $\mathrm{L}$ & High cholesterol \\
\hline Impatiens balsamina $\mathrm{L}$. & Bunga sapa & Herb & $\mathrm{W}$ & $\mathrm{Fl}$ & Abscesses, Kuning \\
\hline Impatiens platypetala Lindley & Bunga pancur & Herb & $\mathrm{W}$ & $\mathrm{Fl}$ & Kuning \\
\hline $\begin{array}{l}\text { Impatiens sp. } \\
\text { Caricaceae }\end{array}$ & Kiung & Herb & $\mathrm{W}$ & $\mathrm{Fl}$ & Itches, Kuning \\
\hline $\begin{array}{l}\text { Carica papaya } \mathrm{L} . \\
\text { Costaceae }\end{array}$ & Bertik & Herb & $\mathrm{C}$ & $\mathrm{L}$ & Fever, cancer \\
\hline $\begin{array}{l}\text { Costus sp. } \\
\text { Cucurbitaceae }\end{array}$ & Tabar-tabar & Herb & $\mathrm{W}$ & $\mathrm{L}$ & Weakness \\
\hline Benincasa hispida (Thunb.) Cogn. & Gundur & Herb & $\mathrm{C}$ & $\mathrm{Se}, \mathrm{Fl}$ & Tawar, Kuning \\
\hline Cucumis sativus L. & Cimen & Herb & $\mathrm{C}$ & $\mathrm{Se}, \mathrm{Fl}$ & Tawar, Kuning \\
\hline $\begin{array}{l}\text { Cucurbita moschata Duchesne } \\
\text { Dennstaedtiaceae }\end{array}$ & Jambe & Herb & $\mathrm{C}$ & $\mathrm{Se}, \mathrm{Fl}$ & Tawar, Kuning \\
\hline $\begin{array}{l}\text { Pteridium aquilinum (L.) Kuhn } \\
\text { Equisetaceae }\end{array}$ & Ersam & Herb & $\mathrm{W}$ & $\mathrm{L}$ & Itches \\
\hline $\begin{array}{l}\text { Equisetum ramosissimum Desf. } \\
\text { Ericaceae }\end{array}$ & Sendep-sendep & Herb & $\mathrm{W}$ & $\mathrm{Wp}$ & Heartburn, Tawar \\
\hline $\begin{array}{l}\text { Gaultheria leucocarpa } \text { Blume } \\
\text { Euphorbiaceae }\end{array}$ & Kalincayo & Wood & $\mathrm{W}$ & $\mathrm{L}$ & Colds, Oukup \\
\hline Aleurites moluccanus (L.) & Kembiri & Wood & $\mathrm{W}$ & $\mathrm{Fr}$ & Appetite enhancer, abscesses \\
\hline Bischofia javanica Blume & Cingkam & Wood & $\mathrm{W}$ & $\mathrm{B}$ & Gastritis \\
\hline $\begin{array}{l}\text { Triadica } \text { sp. } \\
\text { Fabaceae }\end{array}$ & Tawan gegeh & Herb & $\mathrm{W}$ & St & Weakness, Minak \\
\hline $\begin{array}{l}\text { Spatholobus ferrugineus (Zoll. \& } \\
\text { Moritzi) Benth. } \\
\text { Gesneriacea }\end{array}$ & Tawan iket manuk & Herb & W & $\mathrm{Wp}$ & Rheumatic, muscle pain \\
\hline Aeschynanthus albidus (Blume) Steud & Kapal-kapal & Herb & $\mathrm{W}$ & $\mathrm{L}$ & Cancer, Minak \\
\hline $\begin{array}{l}\text { Aeschynanthus sumatranus Ohwi } \\
\text { Gleicheniaceae }\end{array}$ & Sigara tundal & Herb & $\mathrm{W}$ & $\mathrm{L}$ & Fever \\
\hline $\begin{array}{l}\text { Gleichenia linearis (Burm. f.) C.B. } \\
\text { Clarke } \\
\text { Lamiaceae }\end{array}$ & Sumpilpil & Shrub & $\mathrm{W}$ & $\mathrm{L}$ & Abscesses, fever \\
\hline Leucas decemdentata (Willd.) Sm. & Silembur kumpa & Herb & $\mathrm{W}$ & $\mathrm{Wp}$ & Contusion \\
\hline Mentha spicata $\mathrm{L}$. & $\begin{array}{l}\text { Sigarang garang } \\
\text { kuda }\end{array}$ & Herb & $\mathrm{W}$ & $\mathrm{L}$ & Bad breath, stomach ache \\
\hline Coleus amboinicus Lour. & Terbangun meratah & Herb & W & $\mathrm{L}$ & Headache, sprue \\
\hline Coleus scutellarioides L. & Terbangun megara & Herb & W & $\mathrm{L}$ & Fever, stomach ache, abscesses, constipation \\
\hline $\begin{array}{l}\text { Pogostemon cablin (Blanco) Benth. } \\
\text { Lauraceae }\end{array}$ & Nilam & Shrub & W & $\mathrm{L}$ & Wounds, aphrodisiac, cancer \\
\hline $\begin{array}{l}\text { Cinnamomum burmanni (Nees \& } \\
\text { T.Nees) Blume. }\end{array}$ & Kulit manis & Wood & $\mathrm{W}$ & $\mathrm{B}$ & Colds, diabetes, Minak \\
\hline $\begin{array}{l}\text { Persea americana Mill. } \\
\text { Leguminosae }\end{array}$ & Pokat & Wood & $\mathrm{W}$ & $\mathrm{L}$ & Back pain, bladder stone \\
\hline Erythrina fusca Lour. & Dapdap & Shrub & $\mathrm{W}$ & $\mathrm{L}$ & Weakness \\
\hline Cassia tora $\mathrm{L}$. & Kicik-kicik & Herb & $\mathrm{W}$ & Ro & Diarrhea, fever \\
\hline
\end{tabular}




\begin{tabular}{|c|c|c|c|c|c|}
\hline $\begin{array}{l}\text { Mimosa pudica } \mathrm{L} . \\
\text { Liliaceae }\end{array}$ & Pedem-pedem & Herb & $\mathrm{W}$ & $\mathrm{L}$ & Hypertension, bladder stone \\
\hline $\begin{array}{l}\text { Cordyline fructicosa (L.) A.Chev. } \\
\text { Lindsaeaceae }\end{array}$ & Kaling juang & Wood & $\mathrm{W}$ & $\mathrm{L}$ & Fever \\
\hline Odontosaria sp. & Perik kuda & Herb & $\mathrm{W}$ & $\mathrm{L}$ & Oukup \\
\hline $\begin{array}{l}\text { Odontosoria chinensis (L.) J. Sm. } \\
\text { Lycopodiaceae }\end{array}$ & Paku perik & Herb & $\mathrm{W}$ & $\mathrm{L}$ & Itches, Oukup \\
\hline Lycopodium proliferum L. & Terkal & Herb & $\mathrm{W}$ & $\mathrm{L}$ & Aphrodisiac \\
\hline \multicolumn{6}{|l|}{ Malvaceae } \\
\hline Hibiscus rosa-sinensis Linn & $\begin{array}{l}\text { Rudang-rudang } \\
\text { guru }\end{array}$ & Wood & $\begin{array}{l}\mathrm{W} \\
\mathrm{C}\end{array}$ & $\mathrm{L}, \mathrm{Fl}$ & Fever, cough \\
\hline Sida rhombifolia $\mathrm{L}$. & Beras-beras & Wood & W & $\mathrm{Fl}$ & Rheumatism, teeth problems \\
\hline $\begin{array}{l}\text { Urena lobata } \mathrm{L} . \\
\text { Melastomaceae }\end{array}$ & Sampililit & Wood & $\mathrm{W}$ & Ro & Colds, abscesses, bone fractures, headache \\
\hline Medinilla hypericifolia Blume & Surindan kopi & Herb & $\mathrm{W}$ & $\mathrm{L}$ & Cancer \\
\hline $\begin{array}{l}\text { Melastoma malabathricum L. } \\
\text { Meliaceae }\end{array}$ & Senduduk & Wood & W & $\mathrm{Wp}$ & Abscesses, sprue \\
\hline Aglaia odoratissima Blume & Ukat-ukat & Wood & $\mathrm{W}$ & $\mathrm{L}$ & Hypertension, bladder stone \\
\hline $\begin{array}{l}\text { Toona sureni (Blume) Merr. } \\
\text { Molluginaceae }\end{array}$ & Ingul & Wood & $\mathrm{W}$ & $\mathrm{B}$ & Weakness \\
\hline $\begin{array}{l}\text { Molugo sp. } \\
\text { Moraceae }\end{array}$ & Rancang & Wood & W & $\mathrm{L}$ & Diarrhea \\
\hline $\begin{array}{l}\text { Artocarpus heterophyllus Lam. } \\
\text { Musaceae }\end{array}$ & Nangka & Wood & $\mathrm{C}$ & Fr & Gastritis \\
\hline $\begin{array}{l}\text { Musa paradisiaca } \mathrm{L} \text {. } \\
\text { Myrtaceae }\end{array}$ & Galuh & Herb & $\mathrm{C}$ & $\mathrm{L}, \mathrm{St}$ & Stomach ache, fever \\
\hline Eugenia aromatic O.Berg & Cengkeh & Wood & $\mathrm{W}$ & $\mathrm{Fl}, \mathrm{L}$ & Bad breath, cough, teeth problems, Minak \\
\hline Melaleuca leucadendra (L.) L. & Kayu putih & Wood & $\mathrm{W}$ & $\mathrm{L}$ & Colds \\
\hline $\begin{array}{l}\text { Psidium guajava } \mathrm{L} . \\
\text { Pandanaceae }\end{array}$ & Galiman & Wood & $\mathrm{C}$ & $\mathrm{L}$ & Gastritis, diarrhea \\
\hline $\begin{array}{l}\text { Pandanus amaryllifolius Roxb } \\
\text { Piperaceae }\end{array}$ & Pandan & Shrub & $\mathrm{W}$ & $\mathrm{L}$ & Oukup \\
\hline Piper betle L. & Belo & Shrub & $\mathrm{W}$ & $\mathrm{L}$ & Burns \\
\hline Piper nigrum L. & Lada mbiring & Liana & $\mathrm{W}$ & $\mathrm{Fr}$ & $\begin{array}{l}\text { Weakness, appetite enhancer, liver, Oukup, Kuning, } \\
\text { Tawar, Minak }\end{array}$ \\
\hline $\begin{array}{l}\text { Plantaginaceae } \\
\text { Plantago major } \mathrm{L} . \\
\text { Poaceae }\end{array}$ & Patah tulang & Herb & $\mathrm{W}$ & $\mathrm{L}$ & Diabetes, wounds \\
\hline Bambusa sp. & Buluh & Wood & $\mathrm{W}$ & Ro, St & Cancer, Tawar \\
\hline Cymbopogon citratus (DC.) Stapf & Sereh & Herb & $\mathrm{C}$ & $\mathrm{Wp}$ & Appetite enhancer, Oukup, Minak \\
\hline Eleusine indica (L.) Gaertn & Padang teguh & Herb & $\mathrm{W}$ & Ro & Heartburn, Minak \\
\hline Imperata cylindrica (L.) Raeusch. & Rih & Herb & $\mathrm{W}$ & Ro & Diabetes \\
\hline Leersia hexandra Swartz. & Sayat-sayat & Herb & W & $\mathrm{L}$ & Teeth problems \\
\hline Saccharum officinarum L. & Tebu gara & Herb & $\begin{array}{l}\mathrm{W} \\
\mathrm{C}\end{array}$ & St & Minak \\
\hline Polygalaceae & & & & & \\
\hline Polygala paniculata $\mathrm{L}$. & Rumput wangi & Herb & $\mathrm{W}$ & Ro & Colds, Oukup \\
\hline $\begin{array}{l}\text { Polygala sp. } \\
\text { Polygonaceae }\end{array}$ & Tongkap merigat & Herb & W & $\mathrm{L}$ & Aphrodisiac \\
\hline $\begin{array}{l}\text { Persicaria chinensis (L.)H. Gross. } \\
\text { Rosaceae }\end{array}$ & Siang-siang & Herb & $\mathrm{W}$ & $\mathrm{L}$ & Stomach ache \\
\hline Prunus acutissima Urb & Kacihe & Wood & $\mathrm{W}$ & $\mathrm{L}$ & Itches \\
\hline Rubus reflexus Ker & Kopi-kopi kerangen & Wood & $\mathrm{W}$ & $\mathrm{L}$ & Diarrhea, hemorrhoids, leprosy \\
\hline $\begin{array}{l}\text { Rubus pyrifolius Hook.f. \& Thomson } \\
\text { ex Hook.f } \\
\text { Rubiaceae }\end{array}$ & Cancang dori & Wood & W & $\mathrm{L}$ & Gastritis \\
\hline Rubia cordifolia $\mathrm{L}$. & Siraprap igung & Wood & $\mathrm{W}$ & $\mathrm{L}$ & Bladder stones \\
\hline $\begin{array}{l}\text { Uncaria gambir (Hunter) Roxb. } \\
\text { Rutaceae }\end{array}$ & Gamber & Wood & $\mathrm{W}$ & $\mathrm{L}, \mathrm{La}$ & Gastritis, fever, abscesses, coughs, cancer, liver \\
\hline Citrus hystrix DC. & Rimo mungkur & Wood & $\begin{array}{l}\mathrm{W} \\
\mathrm{C}\end{array}$ & $\mathrm{L}, \mathrm{Fr}$ & Fever, diabetes, Oukup, Kuning \\
\hline Citrus nobilis Lour. & Rimo puraga & Wood & $\begin{array}{l}\mathrm{W}, \\
\mathrm{C}\end{array}$ & $\mathrm{L}, \mathrm{Fr}$ & Fever, bone fractures, Oukup, Tawar \\
\hline Solanaceae & & & & & \\
\hline Capsicum annuит $\mathrm{L}$. & Cina & Shrub & $\mathrm{C}$ & Fr & Abscesses \\
\hline Physalis andiabetesta $\mathrm{L}$. & Depuk-depuk & Herb & $\mathrm{W}$ & $\mathrm{L}$ & Bone fractures, abscesses, dislocate, hypertension \\
\hline Nicotiana tabacum $\mathrm{L}$. & Mbako & Wood & $\mathrm{C}$ & $\mathrm{L}$ & Wounds \\
\hline $\begin{array}{l}\text { Solanum verbascifolium L. } \\
\text { Sterculiaceae }\end{array}$ & Lancing & Wood & $\mathrm{W}$ & $\mathrm{L}$ & Dislocate \\
\hline $\begin{array}{l}\text { Abroma sp. } \\
\text { Theaceae }\end{array}$ & Cuping-cuping & Wood & $\mathrm{W}$ & $\mathrm{L}$ & Heart disease \\
\hline $\begin{array}{l}\text { Camellia sinensis (L.) Kuntze } \\
\text { Urticaceae }\end{array}$ & Teh & Shrub & $\mathrm{C}$ & $\mathrm{L}$ & Itches \\
\hline Elatostema strigosum Hassk & Sisik naga & Herb & $\mathrm{W}$ & $\mathrm{L}$ & Fever, weakness \\
\hline Laportea decumana (Roxb.) Wedd & Lateng & Herb & W & Ro & Itches, muscle pain \\
\hline $\begin{array}{l}\text { Poikilospermum sp. } \\
\text { Usneaceae }\end{array}$ & Ober & Wood & W & $\mathrm{L}$ & Stomach ache \\
\hline Usnea barbata Fr. & Nakan angin & $\begin{array}{l}\text { Li- } \\
\text { chene }\end{array}$ & W & $\mathrm{Wp}$ & Weakness \\
\hline
\end{tabular}




\begin{tabular}{|c|c|c|c|c|c|}
\hline $\begin{array}{l}\text { Verbenaceae } \\
\text { Vitex trifolia } \mathrm{L} . \\
\text { Violaceae }\end{array}$ & Salagundi & Wood & W & $\mathrm{L}$ & Eye problems, cough \\
\hline Viola inconspicua Blume & Calung-calung & Herb & W & $\mathrm{L}$ & Stomach ache \\
\hline $\begin{array}{l}\text { Vitaceae } \\
\text { Vitis gracilis BL. } \\
\text { Zingiberaceae }\end{array}$ & Gagatan harimo & Herb & W & $\mathrm{L}$ & Aphrodisiac, stomach ache \\
\hline Alpinia sp. & Laja & Herb & $\mathrm{C}$ & $\mathrm{Rh}$ & Appetite enhancer, diabetes, Oukup, Kuning \\
\hline Alpinia galanga (L.) Willd. & Kelais & Herb & $\mathrm{C}$ & $\mathrm{Rh}$ & Coughs, weakness, Oukup \\
\hline $\begin{array}{l}\text { Boesenbergia pandurata (Roxb.) } \\
\text { Schltr }\end{array}$ & Temu kunci & Herb & $\mathrm{C}$ & $\mathrm{Rh}$ & Appetite enhancer, Oukup \\
\hline Curcuma domestica Valeton & Kuning gersing & Herb & $\mathrm{C}$ & $\mathrm{Rh}$ & $\begin{array}{l}\text { Gastritis, appetite enhancer, weakness, coughs, diabetes, } \\
\text { Kuning }\end{array}$ \\
\hline Curcuma heyneana Valeton \& Zijp & Kuning gajah & Herb & $\mathrm{C}$ & $\mathrm{Rh}$ & Coughs, wounds, Weakness, Oukup \\
\hline Curcuma xanthorrhiza Roxb. & Temulawak & Herb & $\mathrm{C}$ & $\mathrm{Rh}$ & Appetite enhancer, diabetes, Oukup, Kuning \\
\hline Nicolaia speciosa Horan & Cekala/Kincung & Herb & $\mathrm{C}$ & St, L & Weakness, Oukup, Tawar \\
\hline Hedychium coronarium J.Koenig & Bunga ncole & Herb & W & $\mathrm{Fl}$ & Eye problems, Kuning \\
\hline Hedychium cylindricum Ridl & Cekala kabang & Herb & $\mathrm{C}$ & $\mathrm{L}$ & Colds, cough \\
\hline Zingiber sp. & Cekala rih & Herb & $\mathrm{C}$ & $\mathrm{L}$ & Appetite enhancer, coughs, colds \\
\hline Zingiber americanus Blume & Lempuyang & Herb & $\mathrm{C}$ & $\mathrm{Rh}$ & Fever, Weakness, appetite enhancer, Oukup, Kuning \\
\hline Zingiber officinale Blume & Bahing & Herb & $\mathrm{C}$ & $\mathrm{Rh}$ & Fever, appetite enhancer, Oukup, Kuning, Tawar, Minak \\
\hline Zingiber purpureum Roscoe & Bungle & Herb & $\mathrm{C}$ & $\mathrm{Rh}$ & Appetite enhancer, Oukup \\
\hline Zingiber sp. & Alia & Herb & $\mathrm{C}$ & $\mathrm{Rh}$ & Gastritis \\
\hline
\end{tabular}

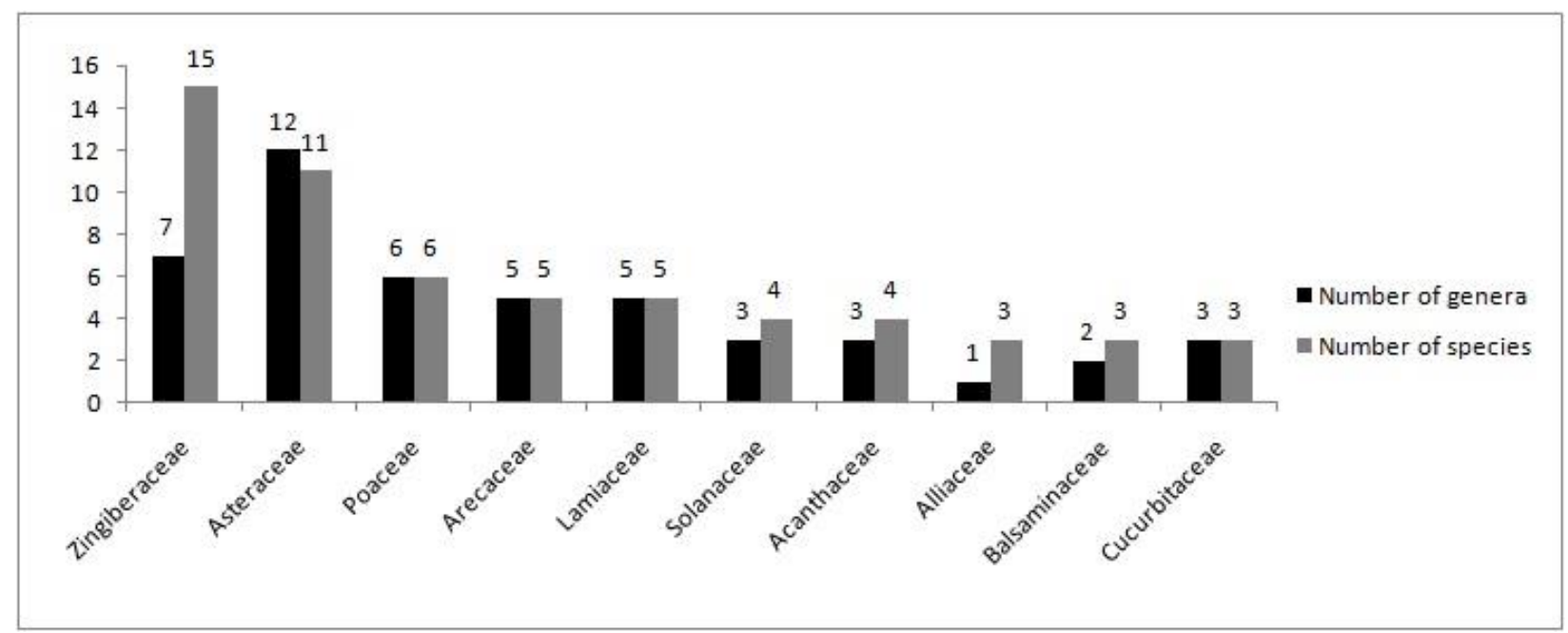

Fig. 2: Most Important Medicinal Plant Families Used by Batak Karo.

Table 2: Plant Parts Used

\begin{tabular}{lll}
\hline Plant Part & Number of Uses & \\
\hline & & $\%$ \\
Leaf & 74 & 51 \\
Root & 14 & 10 \\
Rhizome & 11 & 8 \\
Flower & 10 & 7 \\
Stem & 10 & 7 \\
Fruit & 9 & 6 \\
Whole plants & 8 & 2 \\
Bark & 3 & 2 \\
Seed & 3 & 1 \\
Tuber & 2 & 1 \\
Latex & 1 & 100 \\
\end{tabular}

\section{Discussion}

\subsection{Batak Karo's conceptions of health and diseases}

Most of the respondents are familiar with the plants species which used to treat the common diseases such as fever, weakness, cold, cough and stomach ache. They considered that traditional medicines are important for the health care because it has no side effect to human body.

Indigenous people believe two types of diseases: naturalistic (diseases caused by nature) and personalistic (disease caused by supernatural) (Foster 1976, Florey \& Wolff 1998). Batak Karo is no exception to this case. For Batak Karo people, naturalistic diseases are called bangger and personalistic is kelangen. Bangger are those caused by the malfunctioning of human body such as cold, fever and stomach ache and kelangen are caused by supernatural powers such as evil spirit (begu, kena si mentas-mentas), bad people (tama-tama) and curse. Kengalen is treated with special ritual which conducted by traditional healers. Meanwhile bangger using some various plants species.

Most of the remedies are prepared using fresh plant material. They have some concoction to treat common disease or maintain healthcare of human body: minak, kuning, tawarand oukup. Minak is traditional oil which can be used to treat weakness problems, 
dislocate, bone fractures, dislocate, wounds, burns and cuts Kuning is used to warm body especially for children and after sickness. Tawar is used to treat common colds, warm bodies and as an appetite enhancer. Oukup is steam baths which usually for health care and treat women after childbirth. Though Batak Karo often uses mixtures of a variety of plants for many treatments, they use single plant species for some treatments. For example, Crassocephalum crepidioides - leaf paste is used to treat small cuts and wounds; Hedychium coronarium - the trapped water from its crown is dropped to treat irritated eyes; Psidium guajava - boiled leaves is used to treat diarrhea; Gaultheria leucocarpa leaves are chewed to treat common cold.

To prepare kuning, some medicinal plants are used such as Alpinia sp., Curcuma domestica, C. xanthorriza, Allium sativum, Kaempferia galanga, Impatiens balsamina, Impatiens sp., Piper nigrum, Hedychium coronarium, Benincasa hispida, Cucumis sativus, Cucurbita moschata, Zingiber americanus, Z. officinale, Z. purpureum, Citrus hystrix and Impatiens platypetala. The paste of all the plants are shaped like small balls and dried. The dried kuning is mixed with some drops of water and applied to body after taking a shower in the afternoon or evening. It is caused by the cold temperature at the night.

Tawar is a paste of some plants which is drunk with hot drinking water. There are two types of tawar according to the informants. Firstly, tawar which is used for the special treatments such as male problems, gynecological problems and weak children. The plants are Arenga pinnata, Calamus diepenhorstii, Areca catechu, Cocos nucifera, Nipa fricticans, Hoya sp., Chromolaena odorata, Bambusa sp., Allium cepa, Allium sativum, Piper nigrum, Equisetum ramosissimum, Zingiber officinale and Citrus nobilis. The other one is tawar which used for common ailments such as weakness after sick or fatigue. The plants are Nicolaia speciosa, Piper nigrum, Allium cepa, A. sativum, Zingiber officinale Kaempferia galanga, Cucumis sativus, Cucurbita moschata, and Benincasa hispida. The plants for minak are Triadica sp., Areca catechu, Cocos nucifera, Zingiber officinale , Eugenia aromatic, Piper nigrum, Allium cepa, A. sativum, Hoya sp., Cinnamomum burmanni, Aeschynanthus albidus, Cymbopogon citratus and Eleusine indica. The milk of Cocos nucifera is boiled until it become oil and mixed with the paste another plants.

The plants for oukup are Alpinia galangal, Alpinia sp., Bosenbergia pandurata, Curcuma heyneana, Curcuma xanthorrhiza, Kaempferia galanga, Nicolaia speciosa, Zingiber americanus, Zingiber officinale, Zingiber purpureum, Strobilanthes sp., Gaultheria leucocarpa, Pandanus amaryllifolius, Piper nigrum, Cymbopogon citratus, Polygala paniculata, Coriandrum sativum, Acorus calamus, Odontosaria sp., Odontosoria chinensis, Citrus hystrix and $C$. nobilis. Oukup is used to treat women after giving birth. The plants are added to boiling water and put in a bucket. The woman is placed in a small and closed room. Once the woman is seated, the bucket of decoction is put near the woman.

\subsection{Diseases treated with medicinal plants}

Zingiberaceae tend to be found most frequently used in Indonesia as medicinal plants (Siagian \& Sunaryo 1996, Kuntorini 2005 , Susiarti et al. 2008, Silalahi 2014). Curcuma, Zingiber, Alpinia, Kaempferia and Hedychium plants are extensively studied for their phytochemistry and pharmacological properties (Hartati et al. 2014). Curcuma domestica is an important plant of Curcuma that widely used as medicinal plants and spice in Indonesia. Batak Karo used it to treat gastritis, weakness problems, coughs, diabetes and appetite enhancer. Curcuma domestica has antibacterial (Lutomski et al. 1974, Banerjee \& Nigam 1978, Shankar \& Sreenivasa 1979), antifungal (Banerjee \& Nigam 1978), antioxidant (Phan et al. 2001, Unnikrishnan \& Rao 1996), anticarcinogenic (Goel et al. 2001, Shao et al. 2002). Zingiber is the most commonly used by Batak Karo, 5 species. This is followed by Curcuma (3 species), Alpinia and Hedychium (each 2 species) and Kaempferia (1 species). Although Kaempferia galanga and Hedychium coronarium are locally medicinally used in Indonesia, knowledge on its biological or chemical activities is scarce so that more research needs to be developed in this field (Hartati et al. 2014, de Padua et al. 1999, van Valkenburg \& Bunyapraphatsara 2001).

In addition to Zingiberaceae, Batak Karo uses some species plants of the Zingiberaceae for oukup to treat different ailments and weakness after childbirth. At least 10 species of Zingiberaceae are used to prepare oukup. People in Minahasa, North Sulawesi, Indonesia use 7 species (Alpinia galanga (L.) Willd., Curcuma domestica Valeton, C. xanthorrhiza Roxb., Kaempferia galanga L., Zingiber montanum (Koenig) Link ex Dietr, Z. officinale Roscoe and $Z$. officinale var. rubrum Theilade) for the steam bath, bakera (Zumsteg \& Weckerle 2007). Meanwhile, Balinese use 6 species of Zingiberaceae (Cheilocostus speciosus (J. Koenig) C.D. Specht, Curcuma purpurascens Blume, C. zanthorrhiza Roxb., Kaempferia rotunda L., Zingiber officinale Roscoe and Z. zerumbet (L.) Roscoe ex Smith) for loloh, Balinese herbal drinks (Sujarwo et al. 2015).

The majority of respondents perceived that fever; weakness and loss of appetite are symptoms for all of the various diseases especially for children. Medicinal plants are often used to treat those symptoms. They used leaves or roots Acorus calamus and the flower of Hibiscus rosa-sinensis to treat fever for children. The boiled of Acorus calamus is applied to head and body. The paste of flower of Hibiscus rosa-sinensis is applied to forehead. Batak Simalungun people also use those plant species to treat fever (Silalahi et al. 2015). Weakness can be caused by excessive fatigue and after childbirth or sickness. Nineteen plants species are used to treat weakness. Most of them are the Zingibeaceae such as Alpinia galanga, Curcuma domestica, C. heyneana, Nicolaia speciosa, and Zingiber americanus. The remedies consist of concoction of various plants species that is boiled and drunk as tea or minak, kuning that is applied to whole body.

Mostly medicinal plants are used for health promotion and boost immunity. A total of 46 of 124 plants species are used for traditional decoction: minak, kuning, tawar and oukup. Those traditional decoctions are used to maintain health and immunity for both children and adults. The top three commonly used plants are Zingiber officinale, Piper betle and Kaempferia galanga. Zingiber officinale and Piper betle are used for minak, kuning, tawar and oukup; and Kaempferia galanga is used for kuning, tawar and oukup. The following is a short review of these three plants species.

\subsubsection{Zingiber officinale}

Zingiber officinale is one of the commonly used spices and medicinal plants in Indonesia and around the world. Zingiber officinale is used to treat fever, promote appetite and health in this study. They acknowledged that Zingiber officinale is a useful plant to warm body. Batak Karo lives in highland area so that they use concoction to maintain their body from cold weather such as tawar, kuning and minak. Batak Simalungun use Zingiber officinale to treat gastrointestinal disorders, stomach ache, fever, aphrodisiac, and wound (Silalahi et al. 2015). People in Ben En National Park, Vietnam consider Zingiber officinale is the most important medicinal plants of Zingiberaceae to treat common diseases such as fever, colds, flu, weakness and fror treating women after childbirth (Sam et al. 2008) and also people in Singapore use it to treat bruises, cold, fever, fibromyalgia, hyperlipidemia, gastroenteritis, hair loss, menstrual cramps and menopause symptom (Siew et al. 2014).

Zingiber officinale has been extensively studied for its biological and chemical activities. The rhizomes contain essential oil and oleoresins which responsible for the characteristics ginger flavor and pungency (Singh et al. 2008). It has been studied for its antioxidant (Stoilova et al. 2007, Ali et al. 2008, Singh et al. 2008, Bellik et al. 2013, Bellik et al. 2014), antiviral of human respiratory syncytial virus (HRSV) (Chang et al. 2013), antiemetic (Philips et al. 1993, Sharma et al. 1997), and antiflammatory (Penna et al. 2003, Grzanna et al. 2005). 


\subsubsection{Piper betle}

Piper betle is widely used for cultural and religious practices (Chaveerach et al. 2006, Sujarwo et 1. 2015,) and medicinal plant in Southeast Asia region (Kumar et al. 2010). It is known that the leaves have antiseptic and activity. In Indonesia, $P$. betle is commonly known as sirih. Indonesian have had a long relationship with $P$. betle and are familiar with its uses. The leaves are frequently boiled to treat bad breath and vaginal discharge. Batak Karo people use the leaves for chewing with areca nut (Areca catechu L.), calcium carbonate, and latex of Uncaria gambir. The medicinal importance of $P$. betle is widely acknowledged in some ancient Thai traditional medicine textbooks and traditional healers, whereby leaves alleviate kidney inflammation and thirst from diabetes; treat cough, asthma, and bronchitis.

In our study, respondents used $P$. betle to treat liver, weakness and to boost appetite. The most common method of preparation is to drink the boiled water of $P$. betle leaves. To promote the health, they mixed the leaves with some medicinal plants to make decoction such as oukup, kuning, tawar and minak.

Due to the prevalence of its uses, many studies have been conducted to evaluate its compounds. Some example of the studies include anticancer (Kumar et al. 2010, Fathilah et al. 2010), antibacterial (Ramji et al. 2002, Nalina \& Rahim 2007, Gupta et al. 2009, Tan \& Chan 2014), antioxidant (Fathilah et al. 2010, Pin et al. 2010, Arambewela et al. 2006, Sharma et al. 2009, Tan \& Chan 2014), antidiabetic (Arambewela et al. 2006), anti-inflammatory (Sharma et al. 2009, Kumar et al. 2010, Pin et al. 2010), antialergic (Kumar et al. 2010), and antifungal (Phongpaichit et al. 2005, Kumar et al. 2010, Ali et al. 2010, Caburian \& Osi 2010).

\subsubsection{Kaempferia galanga}

The rhizome of K. galanga is generally used for oukup, kuning and tawar to promote health; and to treat liver, diarrhea, stomach ache. It is widely used as a spice and food flavoring in traditional dishes to boost appetite. $K$. galanga is traditionally used by people in many regions for the treatment of cold, indigestion, headache, toothache, muscular swelling, rheumatism, pectoral and abdominal pains (Kanjanapothi et al. 2004, Ridtitid et al. 2008). In China, it is used as a spice and a medicinal plant which is used to treat hypertension, headache, toothache, rheumatism, dyspepsia, coughs, inflammatory tumor, pectoral and abdominal pains (Huang et al. 2008). The Japanese use the plant as ingredients in ascent bag which is indicated as improving sleep or minimizing stressful situations (Huang et al. 2008). In Malaysia, the leaves and rhizomes are chewed to treat coughs (Ridtitid et al. 2008) and as a local tonic (Othman et al. 2006). In Thailand, the rhizomes are used to treat toothache, scabs, rheumatism, swelling and abdominal pain (Sirirugsa 1997).

The pharmacological activities of $K$. galanga reported thus far include antioxidant (Chanwitheesuk et al 2005, Chan et al. 2009, Hanumantharaju et al. 2010, Sahoo et al. 2014), antimicrobial (Hanumantharaju et al. 2010, Sahoo et al. 2014), antinociceptive (Ridtitid et al. 2008, Sulaiman et al. 2008, Thiengsusuk et al. 2013), antimalarial (Thiengsusuk et al. 2013), anti-inflammatory (Sulaiman et al. 2008, Vittalrao et al. 2011, Thiengsusuk et al. 2013), antibacterial (George \& Pandalai 1949), amebicidal (Chu et al. 1998) and anticancer (Kosuge et al. 1985).

\section{Conclusion}

This study indicates that Batak Karo people in Merdeka subdistrict, Karo regency, North Sumatra are still experimenting and maintaining the health tradition. They are still continue to depend on medicinal plants, at least for treating of some ailments such as fever, weakness, cold, abscesses, cough and stomach ache. They preserve the local knowledge so that it calls for initiatives to conserve the knowledge alongside the repository of medicinal plants in the research area. Furthermore, in the light of the concoction which used many plants species, some of them are need to conduct phytochemical and biological activity studies to generate information which could be used in drugs development.

\section{Acknowledgement}

The authors are grateful for the kindness and cooperation of people in Merdeka sub-district. Special thanks are also due the following people for their help and support of this work: Usman Purba and Rawin Bangun (Medan); Lukas Pawera (Czech University of Life Sciences Prague); and Wendy, Wisnu Wardhana, Ratna Yuniati (Universitas Indonesia).

\section{References}

[1] Ali BH, Blunden G, Tanira MO, Nemmar A (2008) Some phytochemical, pharmacological and toxicological properties of ginger (Zingiber officinale Roscoe): A review of recent research. Food and Chemical Toxicology 46, 409-420. http://dx.doi.org/10.1016/j.fct.2007.09.085.

[2] Ali I, Khan FG, Suri KA, Gupta BD, Satti NK, Dutt P, et al (2010) In vitro antifungal activity of hydroxychavicol isolated from Piper betle L. Annals of Clinical Microbiology and Antimicrob 9(7), 1-9. http://dx.doi.org/10.1186/1476-0711-9-7.

[3] Anderson J (1971) Mission to the East Coast of Sumatra in 1823. Oxford University Press, Singapore.

[4] Arambewela L, Arawwawala M, Rajapaksa D (2006) Piper betle : a potential natural antioxidant. Int. J. Food Sci Technol 41, 10-14. http://dx.doi.org/10.1111/j.1365-2621.2006.01227.x.

[5] Arambewela LSR, Arawwawala LDAM, Ratnasooriya WD (2005) Antidiabetic activities of aqueous and ethanolic extracts of Piper betle leaves in rats. Journal of Ethnopharmacology 102, 239-245. http://dx.doi.org/10.1016/j.jep.2005.06.016.

[6] Balick MJ, Cox PA (1997) Ethnobotanical research and traditional health care in developing countries. In Medicinal plants for forest conservation and health care, volume 92 (Bodeker G, Bhat KKS, Burley J, Vantomme P eds), Rome: Food and Agriculture Organization of the United Nations, pp. 12-23.

[7] Banerjee a \& Nigam SS (1978) Antimicrobial efficacy of the essential oil of Curcuma longa. Indian Journal of Medical Research 68, 864-866.

[8] Bellik Y, Benabdesselam F, Ayad A, Dahmani Z, Boukraa L, Nenmar A, et al. (2013) Antioxidant activity of the essential oil and oleoresin of Zingiber officinale Roscoe as affected by chemical environment. International Journal of Food Properties 16(6), 13041313. http://dx.doi.org/10.1080/10942912.2011.584257.

[9] Bellik Y (2014) Total antioxidant activity and antimicrobial potency of the essential oil and oleoresin of Zingiber officinale Roscoe. Asian Pacific Journal of Tropical Disease 49(1), 40-44. http://dx.doi.org/10.1016/S2222-1808(14)60311-X.

[10] Bernard HR (2002) Research eethods in anthropology: Qualitative and quantitative methods. 3rd ed. Alta-Mitra Press, United States.

[11] Caburian AB \& Osi MO (2010) Characterization and evaluation of antimicrobial activity of the essential oil from the leaves of Piper betle L. E-International Scientific Research Journal 2(1), 2-13.

[12] Chan EWC, Lim YY, Wong SK, Lim KK, Tan SP, Lianto FS, Yong MY (2009) Effects of different drying methods on the antioxidant properties of leaves and tea of ginger species. Food Chemistry 113, 166-172. http://dx.doi.org/10.1016/j.foodchem.2008.07.090.

[13] Chang JS, Wang KC, Yeh CF, Shieh DE, Chiang LC (2013) Fresh ginger (Zingiber officinale I) has anti-viral activity against human respiratory syncytial virus in human respiratory tract cell lines. Journal of Ethnopharmacology 145, 146-151. http://dx.doi.org/10.1016/j.jep.2012.10.043.

[14] Chanwitheesuk A, Teerawutgulrag A, Rakariyatham N (2005) Screening of antioxidant activity and antioxidant compounds of some edible plants of Thailand. Food Chemistry 92, 491-497. http://dx.doi.org/10.1016/j.foodchem.2004.07.035.

[15] Chaveerach A, Mokkamul p, Sudmoon R, Tanee T (2006) Ethnobotany of thr genus Piper (Piperaceae) in Thailand. Ethnobotany Research and Applications 4, 223-231. http://dx.doi.org/10.17348/era.4.0.223-231.

[16] Chu DM, Miles H, Toney D, Ngyuen C, Marciano-Cabral F (1998) Amebicidal activity of plant extracts from Southeast Asia on Acanthamoeba spp. Parasitology Research 84, 746-752. http://dx.doi.org/10.1007/s004360050480. 
[17] De Padua LS, Bunyapraphatsara N, Lemmens RHMJ (1999) Plant resources of South-East Asia No.12(1). Medicinal and poisonous plants. Backhuys Publishers, Leiden.

[18] Fabricant DS, Farnsworth NR (2001) the value of plants used in traditional medicine for drug discovery. Environmental Health Perspectives 109 (1), 69-75. http://dx.doi.org/10.1289/ehp.01109s169.

[19] Fathilah AR, Sujata, R., Norhanom, AW, Adenan MI (2010) Antiproliferative activity of aqueous extract of Piper betle L. and Psidium guajava L. on KB and HeLa cell lines. Journal of Medicinal Plants Research 4, 987-990.

[20] Florey MJ \& Wolff XY (1998) Incantations and herbal medicines: alone ethnomedicinal knowledge in a context of change. Journal of Ethnobiology 18(1), 39-67.

[21] Foster GM (1976) Disease etiologies in non-western medical systems. American Anthropologist 78, 773-782. http://dx.doi.org/10.1525/aa.1976.78.4.02a00030.

[22] George M \& Pandalai KM (1949) Investigations on plant antibiotics (Part IV): further search for antibiotic substances in Indian medicinal plants. Indian J Med Res 37, 169-181.

[23] Goel A., Boland CR, Chauhan DP (2001) Specific inhibition of cyclooxygenase-2(COX-2) expression by dietary curcumin in HT-29 human colon cancer cells. Cancer Letters 172, 111-118. http://dx.doi.org/10.1016/S0304-3835(01)00655-3.

[24] Guimbo ID, Muller J, Larwanou M (2011) Ethnobotanical knowledge of men, women, and children in rural Niger: a mixedmethods approach. Ethnobotany Journal 9, 235-242. http://dx.doi.org/10.17348/era.9.0.235-242.

[25] Gupta S, Kumar N and Gupta SM (2009) Antibacterial and antifungal activity in extract and oil of Piper betle (Linn) landrace Bangla Mahoba. Adv Zool 31, 16-20.

[26] Grzanna R, Lindmark L, Frondoza CG (2005) Ginger-an herbal medicinal product with broad anti-inflammatory actions. Journal of Medicinal Food 8, 125-132. http://dx.doi.org/10.1089/jmf.2005.8.125.

[27] Hanumantharaju N, Shashidhara S, Rajasekharan PE, Rajendra CE (2010) Comparative evaluation of antimicrobial and antioxidant activities of Kaempferia galanga for natural and micropropagated plant. International Journal of Pharmacy and Pharmaceutical Sciences 2(4), 72-75.

[28] Hartati R, Suganda AG, Fidrianny I (2014) Botanical, phytochemical and pharmacological properties of Hedychium (Zingiberaceae)A review. Procedia Chemistry 13, 150-163. http://dx.doi.org/10.1016/i.proche.2014.12.020.

[29] Heinrich M (2000) Ethnobotany and its role in drug development. Phytotherapy Research 14, 479-488. http://dx.doi.org/10.1002/1099-1573(200011)14:7<479::AIDPTR958>3.0.CO;2-2.

[30] Huang L, Yagura T, Chen S (2008) Sedative activity of hexane extract of Kaempferia galanga L. and its active compounds. Journal of Ethnopharmacology 120 http://dx.doi.org/10.1016/j.jep.2008.07.045.

[31] Kanjanapothi D, Panthong A, Lertprasertsuke N, Taesotikul T, Rujjanawate C, Kaewpinit D, et al )2004) Toxicity of crude rhizome extract of Kaempferia galanga L. (Proh Hom). Journal of Ethnopharmacology 90

$359-365$ http://dx.doi.org/10.1016/j.jep.2003.10.020.

[32] Kartawinata K (2004) Biodiversity conservation in relation to plants used for medicines and other products in Indonesia. Journal Tropical Ethnology 1(2), 1-11

[33] Kosuge T, Yokota M, Sugiyama K, Saito M, Iwata Y, Nakura M, et al (1985) Studies of anticancer principles in Chinese medicines. II Cytotoxic prin- ciples in Biota orientalis (L.) ENDL. and Kaempferia galanga L. Chemical and Pharmaceutical Bulletin 33, 55655567. http://dx.doi.org/10.1248/cpb.33.5565

[34] Kuntorini EM (2005) Botani ekonomi suku Zingiberaceae sebagai obat tradisional oleh masyarakat di Kotamadya Banjarbaru. Bioscientiae 2(1), 25-36.

[35] Kumar N, Misra P, Dube A, Bhattacharya S, Dikshuit M, Ranade S (2010) Piper betle Linn. a maligned Pan_asiatic plant with an array of pharmacological activities and prospects for drug discovery. Current Research 99(7), 922-932.

[36] Lutomski J, Kedzia B, Debska W. Effect of an alcohol extract and of active ingredients from Curcuma longa on bacteria and fungi. Planta Medica 26(5), 9-19. http://dx.doi.org/10.1055/s-00281097963.

[37] Mendelsohn R, Balick MJ (1995) the value of undiscovered pharmaceuticals in tropical forests. Economic Botany 49, 223-228. http://dx.doi.org/10.1007/BF02862929.

[38] Nalina T \& Rahim ZHA (2007) the crude aqueous extract of Piper betle L. and its antibacterial effect towards Streptococcus mutans.
Am. J. Biotechnol. Biochem 3, 10-15. http://dx.doi.org/10.3844/ajbbsp.2007.10.15.

[39] Othman R, Ibrahim H, Mohd MA, Mustafa MR, Awang K (2006) Bioassay-guided isolation of a vasorelaxant active compound from Kaempferia galanga L. Phytomedicine 13, 61-66. http://dx.doi.org/10.1016/j.phymed.2004.07.004.

[40] Penna SC, Medeiros MV, Aimbire FSC, Faria-Neto HCC, Sertie JAA, Lopes-Martins RAB (2003) Anti-inflammatory effect of the hydralcoholic extract of Zingiber officinale rhizomes on rat paw and skin edema. Phytomedicine 10, 381-385. http://dx.doi.org/10.1078/0944-7113-00271.

[41] Penny DH \& Singarimbun M (1967) Economic activity among the Karo Batak of Indonesia: a case study in economic change. Bulletin of Indonesia Economic Studies 6, 31-65. http://dx.doi.org/10.1080/00074916712331331028.

[42] Phan TT, See P, Lee ST, Chan SY (2001) Protective effects of curcumin against oxidative damage on skin cell in vitro: its implicationfor wound healing. Journal Trauma 51, 927-931. http://dx.doi.org/10.1097/00005373-200111000-00017.

[43] Phillips S, Ruggier R, Hutchinson SE (1993) Zingiber officinale (Ginger)-an antiemetic for day case surgery. Anaesthesia 48, 715717. http://dx.doi.org/10.1111/j.1365-2044.1993.tb07188.x.

[44] Phongpaichit S, Subhadhirasakul S, Wattanapiromsakul C (2005) Antifungal activities of extracts from Thai medicinal plants against opportunistic fungal pathogens associated with AIDS patients. Mycoses 48(5), 333-338. http://dx.doi.org/10.1111/j.1439 0507.2005.01142.x

[45] Pin KY, Chuah AL, Rashih AA, Mazura MP, Fadzureena J, Vimala S,et al (2010) Antioxidant and anti-inflammatory activities of extracts of betel leaves (Piper betle) from solvents with different polarities. Journal of Tropical Forest Science 22(4), 448-455.

[46] Ramji N, Ramji N, Iyer R, Chandrasekaran S (2002) Phenolic antibacterials from Piper betle in the prevention of halitosis. Journal of Ethnopharmacology 83, 149-152. http://dx.doi.org/10.1016/S03788741(02)00194-0.

[47] Ridtitid W, Sae-wong C, Reanmongkol W, Wongnawa M (2008) Antinociceptive activity of the methanolic extract of Kaempferia galanga Linn. In experimental animals. Journal of Ethnopharmacology 118, 225-230. http://dx.doi.org/10.1016/j.jep.2008.04.002.

[48] Ridtitid W, Sae-wong C, Reanmongkol W, Wongnawa M (2008) Antinociceptive activity of the methanolic extract of Kaempferia galanga Linn. In experimental animals. Journal of Ethnopharmacology 118, 225-230. http://dx.doi.org/10.1016/i.jep.2008.04.002.

[49] Sahoo S, Parida R, Singh S, Padhy RN, Nayak S (2014) Evaluation of yield, quality and antioxidant activity of essential oil of in vitro propagated Kaempferia galanga Linn. Journal of Acute Disease, 124-130. http://dx.doi.org/10.1016/S2221-6189(14)60028-7.

[50] Sam HV, Baas P, Kessler PJA (2008) Traditional medicinal plants in Ben En National Park, Vietnam. Blumea 53, 569-601. http://dx.doi.org/10.3767/000651908X607521.

[51] Sembiring R, Utomo B, Batubara R (2013) Keanekaragaman vegetasi tanaman obat di Hutan Pendidikan Universitas Sumatra Utara kaisan Taman Hutan Raya Tongkoh Kabuaten Karo Sumatra Utara. Peronema Forestry Science Journal 1, 19-22.

[52] Shao ZM, Shen ZZ, Liu CH, Sartippour MR, Go VL, Heber D, et al (2002) Curcumin exerts multiple suppressive effects on human breast carcinoma cells. International Journal of Cancer 98, 234-240. http://dx.doi.org/10.1002/ijc.10183.

[53] Shankar TNB \& Sreenivasa Murthy V (1979) Effect of turmeric (Curcuma longa) fractions on the growth of some intestinal and pathogenic bacteria in vitro. Indian Journal of Experimental Biology $17,1363-1366$.

[54] Sharma SS, Kochupillai V, Gupta SK, Seth SD, Gupta YK (1997) Antiemetic efficacy of ginger (Zingiber officinale) against cisplatin-induced emesis in dogs. Journal of Ethnopharmacology 57, 93 96. http://dx.doi.org/10.1016/s0378-8741(97)00054-8.

[55] Sharma S, Khan IA, Ali I, Ali F, Kumar M, Kumar A, et al (2009) Evaluation of the antimicrobial, antioxidant, and anti-inflammatory activities of hydroxychavicol for its potential use as an oral care agent. Antimicrobial Agents and Chemotherapy 53, 216-222. http://dx.doi.org/10.1128/AAC.00045-08.

[56] Siagian MH \& Sunaryo (1996) Pemanfaatan suku Zingiberaceae sebagai obat tradisional oleh masyarakat Lembak Delapan, Bengkulu. In Indeks Beranotasi Keanekaragaman Hayati (Staf Peneliti Pusat Penelitian Biologi eds), LIPI Bogor, Indonesia, pp. 237-246.

[57] Siew YY, Zareisedehizadeh S, Seetoh WG, Neo SY, Tan CH, Koh HL (2014) Ethnobotanical survey of usage of fresh medicinal plants in Singapore. Journal of Ethnopharmacology 155, 1450-1466. http://dx.doi.org/10.1016/j.jep.2014.07.024 
[58] Silalahi M, Supriatna J, Walujo EB, Nisyawati (2015) Local knowledge of medicinal plants in sub-ethnic Batak Simalungun of North Sumatra, Indonesia. Biodiversitas 16(1), 44-54. http://dx.doi.org/10.13057/biodiv/d160106.

[59] Silalahi M, Nisyawati, Walujo EB, Supriatna J, Mangunwardoyo W (2015) the local knowledge of medical plants trader and diversity of medicinal plants in the Kabanjahe traditional market, North Sumatra, Indonesia. Journal of Ethnopharmacology 175, 432-443. http://dx.doi.org/10.1016/j.jep.2015.09.009.

[60] Silalahi M (2014) the ethnomedicine of the medicinal plants in subethnic Batak, North Sumatra and the conservation perspective. Disertation. Universitas Indonesia, Indonesia.

[61] Singarimbun M (1975) Kinship, descent, and alliances among the Batak Karo. University of California, United States.

[62] Singarimbun M (2007) Kutagamber: a village of the Karo. In Villages in Indonesia (Koentjaraningrat ed), Equinox Publishing, Singapore, pp. 115-128.

[63] Singh G, Kapoor IPS, Singh P, de Heluani CS, de Lampasona MP, Catalan CAN (2008) Chemistry, antioxidant and antimicrobial investigations on essential oil and oleoresins of Zingiber officinale I Food and Chemical Toxicology 46, 3295-3302. http://dx.doi.org/10.1016/j.fct.2008.07.017.

[64] Sirirugsa P (1997) Thai Zingiberaceae: species diversity and their uses. In The International Conference on Biodiversity and Bioresources: Conservation and Utilization, Phuket, Thailand, 23-27 November 1997.

[65] Stoilova I, Krastanov A, Stoyanova A, Denev P, Gargova S (2007) Antioxidant activity of a ginger extract (Zingiber officinale I). Food Chemistry 102, 764-770. http://dx.doi.org/10.1016/j.foodchem.2006.06.023.

[66] Sujarwo B, Keim AP, Savo V, Guarrera PM, Caneva G (2015) Ethnobotanical study of Loloh: traditional herbal drinks from Bali (Indonesia). Journal of Ethnopharmacology 169, 34-48. http://dx.doi.org/10.1016/j.jep.2015.03.079.

[67] Sulaiman MR, Zakaria ZA, Daud IA, Ng YC, Hidayat MT (2008) Antinociceptive and anti-inflammatory activities of the aqueous extract of Kaempferia galanga leaves in animal models. J Nat Med 62 , 221-227. http://dx.doi.org/10.1007/s11418-007-0210-3.

[68] Susiarti S, Purwanto Y, Walujo EB (2008) Medicinal plant diversity in The Tesso Nilo National Park, Riau, Sumatra, Indonesia. Reinwardtia 12(5), 383-390.

[69] Tan YP \& Chan EWC (2014) Antioxidant, antityrosinase and antibacterial properties of fresh and processed leaves of Anacardium occidentale and Piper betle. Food Bioscience 6, 17-23. http://dx.doi.org/10.1016/j.fbio.2014.03.001.

[70] Thiengsusuk A, Chaijaroenkul W, Na-Bangchang K (2013) Antimalarial activities of medicinal plants and herbal formulations used in Thai traditional medicine. Parasitology Research 112, 14751481. http://dx.doi.org/10.1007/s00436-013-3294-6.

[71] Unnikrishnan MK, Rao MN (1995) Inhibition of nitric-induced ox idation of hemoglobin by curcuminoids. Pharmazie 50, 490-492.

[72] Van Valkenburg JLCH \& Bunyapraphatsara N (2001) Plant resources of South-East Asia No.12 (2). Medicinal and poisonous plants 2. Backhuys Publishers, Leiden.

[73] Vittalrao AM, Shanbhag T, Kumari M, Bairy KL, Shenoy S (2011) Evaluation of antiinflammatory and analgesic activities of alcoholic extract of Kaempferia galanga in rats. Indian Journal of Physiology Pharmacology 55(1), 13-24.

[74] Zumsteg IS \& Weckerle CS (2007) Bakera, a herbal steam bath for postnatal care in Minahasa (Indonesia): documentation of the lants used and assessment of the method. Journal of Ethnopharmacology 111, 641-650. http://dx.doi.org/10.1016/j.jep.2007.01.016. 